Effects of early leaf removal on volatile compounds concentrations in Cabernet Sauvignon wines from the Ilok vineyards

Učinci ranog uklanjanja listova na koncentracije hlapljivih spojeva u Cabernet Sauvignon vinima iz vinogorja Ilok

Drenjančević, M., Rastija, V., Jukić, V., Zmaić, K., Kujundžić, T., Rebekić, A., Schwander, F.

Poljoprivreda/Agriculture

ISSN: 1848-8080 (Online)

ISSN: 1330-7142 (Print)

http://dx.doi.org/10.18047/poljo.24.1.2

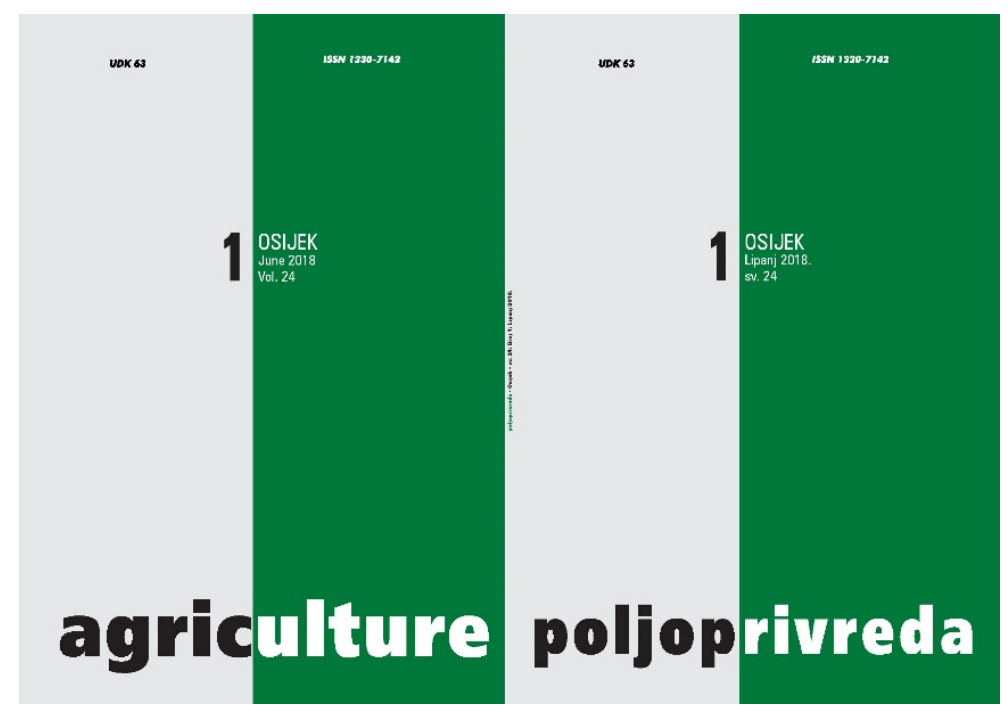

Poljoprivredni fakultet u Osijeku, Poljoprivredni institut Osijek

Faculty of Agriculture in Osijek, Agricultural Institute Osijek 


\title{
EFFECTS OF EARLY LEAF REMOVAL ON VOLATILE COMPOUNDS CONCENTRATIONS IN CABERNET SAUVIGNON WINES FROM THE ILOK VINEYARDS
}

Drenjančević, M. ${ }^{(1)}$, Rastija, V.(1), Jukić, V.(1), Zmaić, K. ${ }^{(1)}$, Kujundžić, $T^{(1)}$, Rebekić, A. ${ }^{(1)}$, Schwander, $F^{(2)}$

Original scientific paper

Izvorni znanstveni članak

\begin{abstract}
SUMMARY
The aim of this two year study was to evaluate effects of basal leaf removal before blooming on volatile composition of Cabernet Sauvignon wines in the llok vineyards (eastern Croatia). During two consecutive vintages $(2013,2014)$, two different treatments of basal leaf removal were applied: removal of 3 and 6 leaves, and control without leaf removal. Volatile compounds of resulting wines were identified and quantified by gas chromatography coupled with mass spectrometry. Organic acids and higher alcohols remained unaffected by treatments of early defoliation wine, except acetic acid and 2-methyl-6-hepten-1-ol. Early leaf removal was affected on six esters concentration only in the 2014 with different outcome. For compounds unaffected by defoliation, vintage was statistically significant source of variability, as the results of multivariate analysis have confirmed. Defoliation treatments in Cabernet Sauvignon wines from eastern continental part of Croatia should be adjusted to the weather condition in growing season.
\end{abstract}

Key-words: leaf removal, wine, volatile compounds, gas chromatography

\section{INTRODUCTION}

Wine flavour and aroma, important aspects of red wine quality, are derived from large range of volatile compounds (e.g. esters, aldehydes, ketones, alcohols, terpenes, etc.) and their interactions. Some of the volatile compounds originate from the grape, some are produced by yeast during fermentation, and some are formed in the aging process (Rapp and Mandery, 1986). Alcohols and aldehydes associated are C6 compounds that are synthesised via the lipoxygenase pathway at harvest, during transportation, crushing, pressing, must heating and grape maceration. Linoleic and $\alpha$-linolenic acids produced by an acyl-hydrolase action are formed by the lipoxygenase activity, which requires oxygen. An alcohol dehydrogenase reduces the alcohols to the corresponding aldehydes i.e. 1-hexanol, (Z)-3-hexenol and (E)-2-hexenol (Oliveira et al., 2006). The study of DiäazMaroto et al. (2005) found that content of branched fatty acid ethyl esters was related to yeast nitrogen metabolism, compared to their straight chain analogues, whose content is related to yeast lipid metabolism.
The aroma of Cabernet Sauvignon is often described as fruity or floral, with roasted, wood-smoke, cooked meat nuances, and often as herbaceous and is associated with different volatile compounds (Preston et al., 2008). The variation of flavour and aroma compounds in ripe grapes depends on variety, environmental conditions during the growing season and cultural practices (Dunlevy et al., 2009). Giovanelli and Brenna (2007) stated that climatic conditions, temperatures during ripening and cluster sun exposure are all significant factors that affect levels of varietal aroma compounds in grape berries. Many researchers have demonstrated that various viticulture practices can affect the composition of volatile compounds in grape and wine, such as irrigation treatment (Chapman et al., 2005); cover crops (Xi et al.,

(1) Assist. Prof. Mato Drenjančević, Assoc. Prof. Vesna Rastija (vesna. rastija@pfos.hr), Assist. Prof. Vladimir Jukić, Prof. Dr. Krunoslav Zmaić, Toni Kujundžić, Ph.D. student, Assoc. Prof. Andrijana Rebekić - Josip Juraj Strossmayer University of Osijek, Faculty of Agriculture in Osijek, Vladimira Preloga 1, 31000 Osijek, Croatia, (2) Florian Schwander. Ph.D. - Julius Kühn-Institut, Federal Research Centre of Cultivated Plants, Institute for Grapevine Breeding 8 Geilweilerhof, 76833 Siebeldingen, Germany 
2011); shoot density and crop-thinning level (Reynolds et al., 1994). Early defoliation is a very innovative viticulture technique used for yield management. The main objective of the fruit zone leaf removal is the microclimate improvement around fruits in order to enhance air circulation, sunlight exposure, grape bunches and health (Tardaguila et al., 2010; Bubola and Peršurić, 2012).

Outcome of defoliation treatments on wine volatiles profile is associated with many factors. Therefore, significantly higher concentrations of wine esters were observed in the defoliation treatment group at earlier harvest (Verzera et al., 2016). The timing of defoliation has great influence on grape composition. Early leaf removal induced C6-compounds concentration increase in Tempranillo wine, but only in one vintage under consideration (Moreno et al., 2017). Šuklje et al. (2014) showed that basal defoliation occured at earlier berry development stage resulted in higher concentration of volatile esters in Sauvignon Blanc. Similarly, another study in Tempranillo reported much higher total acetates and lower wine alcohols in defoliation group at prebloom compared to fruit-set (Vilanova et al., 2012).

Determining appropriate levels of leaf removal for optimum sunlight exposure is important for particular vine growing regions. Although one effect of early defoliation is improvement of leaf and cluster light exposure, over-exposure to sunlight could lead to fruit sunburn and inhibition of colour development (Mijowska et al., 2016). The cluster-zone leaf removal treatments had no influence on concentrations of the $\mathrm{C} 6$ alcohols and aldehydes in Pinot noir vine (Feng et al., 2015). Compared to basal defoliation, apical defoliation resulted in much lower concentration of ethyl acetate, ethyl hexanoate, ethyl octanoate, ethyl decanoate, 3-methylbutyl acetate, and 1-hexanol in Shiraz grapevines (Zhang et al., 2017).
Limited numbers of studies have investigated the influence of leaf removal on composition and concentration of volatile compounds in red wine. Also, no investigations have been done so far on benefits of early leaf removal performed on red grape cultivars grown in continental part of Croatia on wine aroma compounds. The aim of this two year study was to evaluate the given effects on composition of volatile compounds in Cabernet Sauvignon (Vitis vinifera L.) wine made from grape grown in the vineyard llok, located in eastern continental region of Croatia.

\section{MATERIAL AND METHODS}

\section{Plant material and experimental design}

This study was conducted with grapes of the $V$. vinifera variety Cabernet Sauvignon, in 2013 and 2014. The vineyard, planted in 1999, is located in llok, the eastern continental region of Croatia, subregion Podunavlje, vineyards Srijem. Vine training system was Guyot with 12 buds per plant. The vines were planted with $2.0 \mathrm{~m}$ spacing between rows and $0.9 \mathrm{~m}$ within rows, for a total of 5555 vines/ha. The experiment is designed by random block formation consisted of three replicates.

Two different treatments of basal leaf removal were done: 3 (T1) and 6 leaf (T2) removal before blooming, and control (no leaf removal) (T3). The treatments consisted of 10 plants by plot. The date of harvest was determined according to sugars and acid content. The region has a continental climate. Rainfall and daily mean temperature for 2013 and 2014 between April and September were obtained from Meteorological and Hydrological Service of Croatia and presented in Table 1. Daily mean temperatures, during April-September vegetation period in 2013, were higher than in 2014 while cumulative rainfalls were higher in 2014.

Table 1. Weather conditions in llok during the vegetation period in 2013 and 2014

Tablica 1. Vremenski uvjeti u Iloku tijekom perioda vegetacije 2013. i 2014. godine

\begin{tabular}{|l|c|c|c|c|}
\hline \multirow{2}{*}{ Month - Mjesec } & \multicolumn{2}{|c|}{$\begin{array}{c}\text { Mean daily temperature, }{ }^{\circ} \mathrm{C} \\
\text { Prosječna dnevna temperatura, }{ }^{\circ} \mathrm{C}\end{array}$} \\
\cline { 2 - 5 } & 2013 & 2014 & 2013 & 2014 \\
\hline \multirow{2}{*}{ April } & 13.54 & 13.30 & 30.60 & 55.60 \\
\hline May & 17.05 & 16.27 & 164.10 & 236.40 \\
\hline June & 20.29 & 20.68 & 103.40 & 22.40 \\
\hline July & 23.16 & 21.87 & 14.70 & 149.70 \\
\hline August & 23.19 & 20.87 & 39.40 & 83.70 \\
\hline September & 16.09 & 17.13 & 92.30 & 99.30 \\
\hline October & 14.20 & 13.60 & 58.0 & 68.8 \\
\hline Mean temp. $\left({ }^{\circ} \mathrm{C}\right)$ & 18.22 & 17.67 & & \\
\hline Cumulative rainfall $(\mathrm{mm})$ & & & 502.5 & 715.9 \\
\hline
\end{tabular}

\section{Microvinification}

Fermentations were carried out per each treatment in triplicate for the both investigation years. Grapes were destemmed, crushed, treated with $15 \mathrm{mg} / \mathrm{L} \mathrm{SO}_{2}$ and inoculated with Saccharomyces cerevisiae (Uvaferm $\mathrm{BDX})$. Fermentations were conducted in 5 -litre glass fer- 
mentors at a temperature of $25^{\circ} \mathrm{C}$. Pomace was mixed two times per day. After seven days of fermentation and maceration pomace was pressed using a small mechanical press. Wines were sulphited with $20 \mathrm{mg} / \mathrm{L}$ $\mathrm{SO}_{2}$. Three months after the end of fermentation wines were taken for the analyses.

\section{Analysis of wine quality parameters by Fourier- transform infrared spectroscopy (FTIR)}

The equipment used for analysis of wine quality parameters was a WineScan ${ }^{\mathrm{TM}} \mathrm{SO}_{2}$ (FOSS Analytical, Hilleroed, Denmark). The WineScan SO2 has a Fourier Transform Infrared (FTIR) according to the method published by Moreira and Santos (2005). The response variables were: alcohols ( $\mathrm{vol} \%) ; \mathrm{pH}$; total acidity $(\mathrm{g} / \mathrm{L})$, and organic acids ( $\mathrm{g} / \mathrm{L}$ ): lactic, malic, and tartaric acid. The analyses were performed in triplicate.

\section{GS/MS analysis of volatile compounds}

Volatile compounds were analysed using Agilent $6890 \mathrm{~N}$ gas chromatograph (GC) (Santa Clara, USA) coupled to a mass spectrophotometric (MS) detector along with stir bar sorptive extraction with polydimethylsiloxane phase (Gerstel, Mülheim an der Ruhr, Germany). Identification of the separated compounds was performed by retention indices and MS spectra compared with Wiley 7 Nist 05 mass spectral database. The quantification was done by using 3-decanol as the internal standard. System software control, data management, and analysis were performed through enhanced ChemStation Software (Agilent Techonologies, Inc.). All the samples were analysed in triplicate.

Comparisons of volatile compounds concentrations between different treatments and between years were made using analysis of variance (one-way ANOVA) with the least significant different (LSD) test used to examine the means at the $p=0.05$ level. Multivariate data analysis, principal component analysis (PCA) and cluster analysis were used to examine the effects of early leaf removal treatments on volatile compounds. Statistical analyses were done using SAS 9.3. Software for Windows, Copyright (C) 2012 by SAS Institute Inc., Cary, NC, USA.

\section{RESULTS AND DISCUSSION}

Results of FTIR analysis for alcohols, $\mathrm{pH}$, total acidity and organic acids are presented in Table 2. Defoliation was affected only alcohol content in 2013. Significant increase of alcohols was occurred in wine treated with 6 leaf removal. Vilanova et al. (2012) also noticed that early leaf removal led to wines of higher alcohol content. Sudden increase in light and temperature caused by early leaf removal might lead to greater synthesis of alcohol.

Table 2. Effects of early leaf removal treatments on main chemical parameters in wine cv. Cabernet Sauvignon* ** T1 = Removal of 3 leaves; T2 = Removal of 6 leaves; T3 = control (no leaf removal)

Tablica 2. Učinak ranog uklanjanja listova na glavne kemijske parametre vina sorte Cabernet Sauvignon ${ }^{*}{ }^{* *} T 1=$ Uklanjanje 3 lista; T2 = Uklanjanje 6 listova; T3 = kontrola (bez uklanjanja listova)

\begin{tabular}{|l|c|c|c|c|c|c|}
\hline Parameter - Pokazatelj & T1 2013 & T2 2013 & T3 2013 & T1 2014 & T2 2014 & T3 2014 \\
\hline Alcohol (vol \%) & $10.13^{\mathrm{Bb}}$ & $10.61^{\mathrm{A}}$ & $10.07^{\mathrm{Bb}}$ & $10.8^{\mathrm{a}}$ & 10.99 & $11.06^{\mathrm{a}}$ \\
\hline $\mathrm{pH}$ & 3.54 & $3.54^{\mathrm{a}}$ & 3.53 & 3.46 & $3.44^{\mathrm{b}}$ & 3.4 \\
\hline Total acidity*** $(\mathrm{g} / \mathrm{L})$ & 5.87 & 5.8 & $5.9^{\mathrm{b}}$ & 6.86 & 7.03 & $7.6^{\mathrm{a}}$ \\
\hline Lactic acid (g/L) & 1.53 & 1.23 & 1.5 & 1.8 & 1.4 & 0.8 \\
\hline Malic acid (g/L) & 0.23 & 0.2 & $0.23^{\mathrm{b}}$ & 1 & 1.37 & $1.97^{\mathrm{a}}$ \\
\hline Tartaric acid (g/L) & 1.57 & 1.63 & 1.57 & 1.5 & 1.6 & 1.67 \\
\hline
\end{tabular}

* Quantification was performed using FTIR

** Different lower case letters in rows indicate statistically significant differences $(p<0.05)$ between the years by the LSD test. Different upper case letters in rows indicate statistically significant differences $(p<0.05)$ between treatments by LSD test

*** as tartaric acid

The effect of the season can be noticed in content of alcohol that was higher in 2014 in wine treated with $\mathrm{T} 1$ and T3 treatments, as well as total acidity and malic acid in control wines. Relatively low temperature level in autumn 2013 resulted in prolonged fermentation and low alcohol content in wine. Also, higher cumulative rainfall during vegetation period in 2014 resulted in lower suger content in must and therfore, lower alcohol content in wine. Moreover, $\mathrm{pH}$ is higher in wine from 2013 where 6 leaves were removed.
The results of GC/MS analysis for volatile compounds are presented in Table 3. Volatiles were classified into: organic acids, higher alcohols, and esters. The two most abundant volatile acids found in wines are decanoic acid and octanoic acid, whose concentrations are below $0.20 \mathrm{mg} / \mathrm{L}$. Although, octanoic acid, at low concentrations can cause a cheese, and decanoic acid a rancid flavour in wine, their impact on aroma to wine could be neglected. Heptanoic acid is trace compounds characteristic for Cabernet Sauvignon wine (Jiang and 
Zhang, 2010). No differences among treatments were observed in the concentration of identified volatile organic acids, except acetic acid in season 2013, whose concentration is significantly reduced by early defoliation treatment. Concentrations of the most individual acids vary only between years, and higher levels were observed in 2013, compared to 2014. Higher rainfall during vegetation period in 2014 and lower temperature caused increased malic acid concentration. Malic acid is synthesised during grape berry development. Lower temperature during harvesting could be resulted in malic acid amounts increase (Volschenk et al., 2006).

Higher total acidity, especially in the form of malic acid could be a great problem in cooler climate region (Smith et al., 1988). In accordance to previous studies (Vilanova et al., 2012; Šuklje et al., 2014), our results showed that organic acids remained generally unaffected by early defoliation. It could be explained by facts that organic acids are mainly produced by fermentation and their production mostly depends on the must composition and its fermentation condition (Sánchez-Palomo et al., 2012). On the contrary, samples treated with leaf removal performed at veraison stage on Sauvignon blanc and Riesling cultivars resulted in higher concentrations of tartaric acid in grapevine juice and corresponding wines. Differences between cultivars are explained by genotype and variations in grapevine canopy porosity, impacting light exposure and temperature in the fruit zone (Bubola et al., 2012).

According to the quantitative data reported in Table 3, 2-phenylethanol is the most abundant alcohol in the analysed wine. The results of alcohol concentrations presented in Table 3 show no differences between control and basal leaf removal treatments, with the exception of 2-methyl-6-hepten-1-ol, whose higher concentration was affected by removal of, both 3 and 6 leaves. Significant differences between years were observed for eight of the 12 alcohols. The concentrations of two phenyl alcohol (phenylmethanol and 3-phenyl-1-propanol), as well as, 3-hexen-1-ol, (Z)- and 2-methyl-6hepten-1-ol are higher in 2013. Higher level of 2-nonanol from 2013 was found out only in wine treated by six leaf removal. The significant higher level of other three alcohols (1-hexanol, 1-heptanol and 2-methyl-1-propanol) was found out in wines from 2014. Absence of effects of early defoliation on higher alcohols is consistent with the results of Kozina et al. (2008) for Sauvignon Blanc and Riesling wines. They reported that phenylmethanol was the only higher alcohol whose concentration was strongly affected by leaf removal treatments in both varieties, since it was the only compound arisen from grapes, not produced during alcohol fermentation.

Table 3. Effects of early leaf removal treatments on volatile compounds content $\left(\gamma / \mu \mathrm{g} \mathrm{L}^{-1}\right)$ in wine cv. Cabernet Sauvignon ${ }^{* * *}$ T1 = Removal of 3 leaves; T2 = Removal of 6 leaves; T3 = control (no leaf removal)

Tablica 3. Učinak ranog uklanjanja listova na sadržaj hlapljivih spojeva $\left(\mathrm{y} / \mu \mathrm{g} L^{-1}\right)$ u vinu sorte Cabernet Sauvignon ${ }^{*}{ }^{* *} T 1=$ Uklanjanje 3 lista; T2 = Uklanjanje 6 listova; T3 = kontrola (bez uklanjanja listova)

\begin{tabular}{|c|c|c|c|c|c|c|}
\hline Compound - Sastojak & T1 2013 & T2 2013 & T3 2013 & T1 2014 & T2 2014 & T3 2014 \\
\hline \multicolumn{7}{|l|}{ Organic acid } \\
\hline Acetic acid & $1.30^{\mathrm{Cb}}$ & $2.51^{\mathrm{B}}$ & $4.13^{\mathrm{A}}$ & $3.93^{\mathrm{a}}$ & 3.53 & 3.82 \\
\hline Heptanoic acid & 2.36 & 2.61 & 2.36 & 3.45 & 2.15 & 2.00 \\
\hline 9-Decenoic acid & 4.00 & 3.89 & 4.51 & 2.94 & 1.9 & 2.88 \\
\hline Tetradecanoic acid & $3.82^{\mathrm{a}}$ & $4.03^{\mathrm{a}}$ & $3.83^{\mathrm{a}}$ & $2.33^{b}$ & $2.16^{\mathrm{b}}$ & $2.17^{b}$ \\
\hline Dodecanoic acid & $11.25^{\mathrm{a}}$ & $11.62^{\mathrm{a}}$ & $11.28^{\mathrm{a}}$ & $5.48^{b}$ & $4.62^{b}$ & $5.00^{b}$ \\
\hline Nonanoic acid & 15.13 & $18.33^{\mathrm{a}}$ & $18.38^{\mathrm{a}}$ & 12.25 & $8.29^{b}$ & $9.72^{b}$ \\
\hline Decanoic acid & $146.44^{\mathrm{a}}$ & $152.31^{\mathrm{a}}$ & $152.18^{\mathrm{a}}$ & $70.97^{b}$ & $57.0^{\mathrm{b}}$ & $65.89^{b}$ \\
\hline Octanoic acid & 117.07 & $136.17^{\mathrm{a}}$ & 132.77 & 101.64 & $78.41^{\mathrm{b}}$ & 93.62 \\
\hline \multicolumn{7}{|l|}{ Higher alcohols } \\
\hline 1-hexanol & $13.66^{\mathrm{b}}$ & $13.52^{\mathrm{b}}$ & $13.77^{\mathrm{b}}$ & $21.00^{\mathrm{a}}$ & $19.90^{\mathrm{a}}$ & $19.67^{\mathrm{a}}$ \\
\hline 3-Hexen-1-ol, (Z)- & 10.34 & $10.13^{\mathrm{a}}$ & $10.30^{\mathrm{a}}$ & 6.13 & $3.98^{\mathrm{b}}$ & $3.76^{\mathrm{b}}$ \\
\hline 2-Nonanol & 2.18 & $2.27^{\mathrm{a}}$ & 2.19 & 1.85 & $1.78^{\mathrm{b}}$ & 1.81 \\
\hline 2-Methyl-6-hepten-1-ol & 0.92 & $1.02^{\mathrm{a}}$ & $0.96^{\mathrm{a}}$ & $0.84^{\mathrm{A}}$ & $0.83^{\mathrm{Ab}}$ & $0.63^{\mathrm{Bb}}$ \\
\hline 1-Heptanol & 1.30 & $1.01^{\mathrm{b}}$ & 1.36 & 1.74 & $1.66^{\mathrm{a}}$ & 1.83 \\
\hline 1-Nonanol & 5.91 & 6.11 & 5.51 & 7.28 & 7.21 & 5.87 \\
\hline 3-Phenyl-1-propanol & $4.99^{\mathrm{a}}$ & 4. $40^{\mathrm{a}}$ & $4.49^{\mathrm{a}}$ & $2.23^{b}$ & $2.37^{\mathrm{b}}$ & $2.44^{b}$ \\
\hline 2-Phenylethanol & 1062.33 & 1068.42 & 1094.63 & 1004.54 & 975.71 & 1073.81 \\
\hline Phenylmethanol & $13.42^{\mathrm{a}}$ & $13.00^{\mathrm{a}}$ & $13.47^{\mathrm{a}}$ & $2.25^{\mathrm{b}}$ & $2.68^{b}$ & $2.12^{\mathrm{b}}$ \\
\hline 4-Methyl-1-pentanol & 0.61 & 0.71 & 0.65 & 0.66 & 0.50 & 0.71 \\
\hline 3-Methyl-1-pentanol & $16.36^{b}$ & 15.15 & 16.72 & $19.64^{\mathrm{a}}$ & 17.73 & 20.46 \\
\hline
\end{tabular}




\begin{tabular}{|c|c|c|c|c|c|c|}
\hline Compound - Sastojak & T1 2013 & T2 2013 & T3 2013 & T1 2014 & T2 2014 & Т3 2014 \\
\hline 2-Methyl-1-propanol & $3.00^{b}$ & $2.57^{b}$ & 2.71 & $37.66^{a}$ & $54.78^{a}$ & $54.49^{a}$ \\
\hline \multicolumn{7}{|l|}{ Esters } \\
\hline Ethylphenylacetate & 10.43 & 11.78 & 10.86 & 14.94 & 19.65 & 16.03 \\
\hline Acetic acid hexyl ester & $1.55^{\mathrm{b}}$ & $2.50^{\mathrm{B}}$ & $3.87^{\mathrm{A}}$ & $3.86^{\mathrm{a}}$ & 3.52 & 3.73 \\
\hline Methyl salicylate & 1.61 & 1.15 & 2.39 & 1.13 & 1.40 & 1.57 \\
\hline Ethyl salicylate & 1.81 & 1.43 & 2.31 & 1.41 & 1.76 & 2.21 \\
\hline Cinnamic acid ethyl ester & 11.98 & 8.67 & 10.94 & 6.00 & 7.82 & 8.30 \\
\hline Ethyl 2-hydroxy-3-phenylpropanoate & $94.44^{\mathrm{a}}$ & $89.88^{\mathrm{a}}$ & $97.26^{\mathrm{a}}$ & $58.60^{\mathrm{b}}$ & $67.76^{\mathrm{b}}$ & $65.05^{b}$ \\
\hline 1-Propyltridecyl hexanoate & 69.94 & 65.80 & $56.45^{b}$ & 99.88 & 94.22 & $142.29^{\mathrm{a}}$ \\
\hline Diethyl pimelate & 2.81 & 2.80 & $2.39^{a}$ & 2.08 & 2.24 & $1.46^{b}$ \\
\hline Methyl cinnamate & $2.02^{\mathrm{a}}$ & 1.62 & $1.57^{\mathrm{a}}$ & $0.77^{\mathrm{b}}$ & 0.71 & $0.89^{b}$ \\
\hline Ethyl 3-hydroxytridecanoate & $25.48^{b}$ & $23.41^{b}$ & $26.33^{b}$ & $41.93^{\mathrm{a}}$ & $40.39^{a}$ & $39.73^{\mathrm{a}}$ \\
\hline Diethyl suberate & 6.51 & 7.28 & 5.78 & 5.96 & 6.85 & 5.10 \\
\hline Pentanedioic acid, diethyl ester & $7.91^{\mathrm{a}}$ & $7.69^{\mathrm{a}}$ & 7.61 & $3.90^{\mathrm{b}}$ & $5.15^{b}$ & 5.20 \\
\hline Acetic acid, 2-phenylethyl ester & $234.48^{\mathrm{b}}$ & $213.63^{b}$ & 288.41 & $394.49^{a}$ & $350.51^{\mathrm{a}}$ & 414.66 \\
\hline Hydrocinnamic acid, ethyl ester & $1.55^{\mathrm{Aa}}$ & $0.94^{\mathrm{B}}$ & $1.34^{\mathrm{AB}}$ & $0.71^{\mathrm{b}}$ & 0.67 & 0.94 \\
\hline Isopentyl methoxyacetate & 89.92 & $79.88^{b}$ & 89.08 & $101.77^{\mathrm{AB}}$ & $127.78^{\mathrm{Aa}}$ & $68.91^{\mathrm{B}}$ \\
\hline 2-Furoic acid, ethyl ester & $5.78^{\mathrm{a}}$ & $6.56^{\mathrm{a}}$ & 7.25 & $3.75^{b}$ & $4.67^{b}$ & 4.56 \\
\hline Butanedioic acid, diethyl ester & 2529.77 & 2834.34 & 2711.75 & 2900.0 & 3478.54 & 3001.74 \\
\hline Octanoic acid, ethyl ester & 64.52 & 80.42 & 66.82 & 71.62 & 82.26 & 68.96 \\
\hline Ethyl 2-hydroxyhexanoate & 7.61 & $8.31^{\mathrm{a}}$ & 7.08 & 5.92 & $6.45^{b}$ & 6.55 \\
\hline Ethyl heptanoate & $2.15^{b}$ & 3.04 & 2.49 & $2.79^{a}$ & 3.46 & 3.03 \\
\hline Ethyl lactate & $61.59^{A}$ & $49.42^{B}$ & $53.88^{\mathrm{AB}}$ & 51.05 & 44.90 & 41.57 \\
\hline Isoamyl acetate & $1551.46^{\mathrm{Bb}}$ & $1814.88^{\mathrm{ABb}}$ & $2175.98^{\mathrm{Ab}}$ & $3391.50^{\mathrm{a}}$ & $3796.26^{a}$ & $3860.29^{\circ}$ \\
\hline Ethyl valerate & $0.741^{b}$ & $0.77^{b}$ & $0.70^{b}$ & $1.01^{\mathrm{Ca}}$ & $1.68^{\mathrm{Aa}}$ & $1.19^{\mathrm{Ba}}$ \\
\hline Amyl acetate & 1.32 & $1.13^{\mathrm{a}}$ & $1.13^{\mathrm{a}}$ & 0.62 & $0.57^{b}$ & $0.56^{\mathrm{b}}$ \\
\hline Ethyl hexanoate & 59.09 & 63.33 & 59.18 & 58.64 & 60.60 & 58.26 \\
\hline Isobutyl acetate & $7.30^{\mathrm{b}}$ & $5.42^{b}$ & $7.47^{b}$ & $19.23^{\mathrm{a}}$ & $23.01^{\mathrm{a}}$ & $20.92^{\mathrm{a}}$ \\
\hline Ethyl butyrate & $53.19^{b}$ & $57.19^{b}$ & $54.48^{b}$ & $116.12^{\mathrm{a}}$ & $149.58^{\mathrm{a}}$ & $139.02^{\mathrm{a}}$ \\
\hline Ethyl 2-methylbutyrate & $9.50^{b}$ & 12.16 & $10.57^{b}$ & $15.57^{\mathrm{a}}$ & 14.48 & $17.55^{\mathrm{a}}$ \\
\hline Ethyl isovalerate & 13.66 & 19.82 & $15.13^{b}$ & 21.29 & 19.48 & $24.63^{\mathrm{a}}$ \\
\hline Ethyl acetate & $49.13^{b}$ & $40.42^{b}$ & $51.92^{b}$ & $247.30^{\mathrm{a}}$ & $322.99^{\mathrm{a}}$ & $339.49^{\mathrm{a}}$ \\
\hline Ethyl isobutyrate & $3.47^{\mathrm{b}}$ & $3.30^{\mathrm{b}}$ & $3.49^{b}$ & $12.46^{\mathrm{a}}$ & $13.77^{\mathrm{a}}$ & $15.59^{a}$ \\
\hline Vanillic acid, ethyl ester & $234.58^{\mathrm{a}}$ & $273.59^{\mathrm{a}}$ & $229.97^{\mathrm{a}}$ & $104.42^{b}$ & $108.77^{\mathrm{b}}$ & $104.64^{b}$ \\
\hline
\end{tabular}

* Quantification was performed using 3-decanol as an internal standard

** Different lower case letters in rows indicate statistically significant differences $(p<0.05)$ between the years by the LSD test. Different upper case letters in rows indicate statistically significant differences $(p<0.05)$ between the treatments by LSD test.

n.a. $=$ not available

Higher alcohols formed during fermentation are mostly influenced by winery practices (Antonelli et al., 1999). However, basal leaf removal before bloom led to higher contents of higher alcohols in Istrian Malvasia wines (Bubola et al., 2012). Also, study of Vilanova et al. (2012), showed significant decrease of $\mathrm{C6}$ alcohol (hexanol, hexenol) when defoliation was applied, but total alcohols remained unaffected. The most abundant alcohol found in wines, 2-phenylethanol, assessed in the present study was reported as primary volatile compound in Cabernet Sauvignon (Tao and Zhang, 2010).
The most abundant esters found (concentration $>100 \mu \mathrm{g} / \mathrm{L}$ ) are: acetic acid, 2-phenylethyl ester; butanedioic acid, diethyl ester; isoamyl acetate; vanillic acid, ethyl ester (Table 3). These esters have a significant effect on wine aroma perception as fruity and floral. In the present work, the most significant ester is butanedioic acid, diethyl ester (or diethyl succinate), the compound that gave a vinous aroma, typical for Cabernet Sauvignon (Sánchez-Palomo et al., 2012). The second is isoamyl acetate, which contributes to banana aroma (Jiang and Zhang, 2010). From the total of 32 
identified esters, concentrations of only six of them have been affected by early defoliation. Positive effect of 6 leaf removal was observed only for ethyl valerate in wine from 2014. The same year, both treatments of defoliation resulted in significantly higher concentration of isopentyl methoxyacetate in 2014. Reducing ester concentration by defoliation treatments was noticed only in wine from 2013. Concentration of isoamyl acetate was lowered by the 3 leaf removal treatment; hydrocinnamic acid, ethyl ester and ethyl lactate by the 6 leaf removal treatment, while the both treatments equally reduced the concentrations of acetic acid, hexyl ester. The vintage shown was the largest and statistically significant sources of variability of esters. Significant higher concentrations of seven esters were observed in wines from 2013 year, 10 esters have higher concentrations wines from 2014. In the present study, relation between certain groups of esters, whose concentration was increased or decreased by defoliation treatments, has not been noticed. Thus, Vilanova et al. (2012) reported that early defoliation significantly reduced the C6-compounds and increased the concentrations of acetates in the wines. The negative influence of partial leaf removal was noted in white wine varieties, Sauvignon Blanc and Riesling (Kozina et al., 2008). Reducing effect of defoliation on esters was detected only in the season 2013 while an increase of esters was observed in season 2014. Probably, along with higher seasonal temperatures in 2013, defoliation additionally increased losses of certain volatile esters. This confirms previous findings about limits of the leaf removal. The study has showed that berry quality increased in the year unfavourable for ripening, while the warmer years observed no quality improvement in must and wine (Guidoni et al., 2008; Verzera et al., 2016).

PCA performed on the wine volatile concentration is shown in Fig. 1a PCA resulted in a two-dimensional solution accounting for $91.26 \%$ of the total variance in the data, of which $84.58 \%$ was accounted by PC1 and $6.68 \%$ by PC2. Therefore, almost all the variations in the data are explained by the first two principal components. Wines from the 2013 season were located on the positive side of the $\mathrm{PC} 1$, while the wines from 2014 on the negative side of PC1.The wines treated with 6 leaf removal (T2) were situated on the positive side of the PC2, while control wines (T3) and wines treated with 3 leaf removal (T2) on the negative side of PC2. The cluster analysis was performed using the content of volatile compounds that showed significant differences in concentration by ANOVA as variable. Cluster formation is graphically presented by the dendrogram in Fig. 1b. The first remote cluster was formed from 2013 data, while the second cluster was formed by data from 2014. The results of multivariate analysis confirmed the significant effect of vintage on the concentration of volatiles. In contrast to 2014, majority of organic acids and alcohols showed higher concentration in 2013. This is the most probably due to the warmer and dryer weather conditions during the vegetation period. For the different esters, inconsistent trends between the two seasons were noticed. While the concentration of some esters is considerably higher in 2013 , others have higher concentrations in 2014. Relevance of the vintage effect on volatile compounds, as well as, wine aroma attributes, have been reported previously.

\section{CONCLUSION}

Volatile organic acids and alcohols remained mainly unaffected by treatments of early defoliation in Cabernet Sauvignon wines produced under the climate conditions of eastern continental Croatia. Early leaf removal has influence in one year of the experiment on the concentration of six esters only: isopentyl methoxyacetate, isoamyl acetate, hydrocinnamic acid, ethyl ester, ethyl lactate, and acetic acid, hexyl ester. Lack of larger differences between control and treated wines may be attributed to the seasonal weather conditions. Vintage was found to be the largest source of variability for most volatile compounds under the investigation.
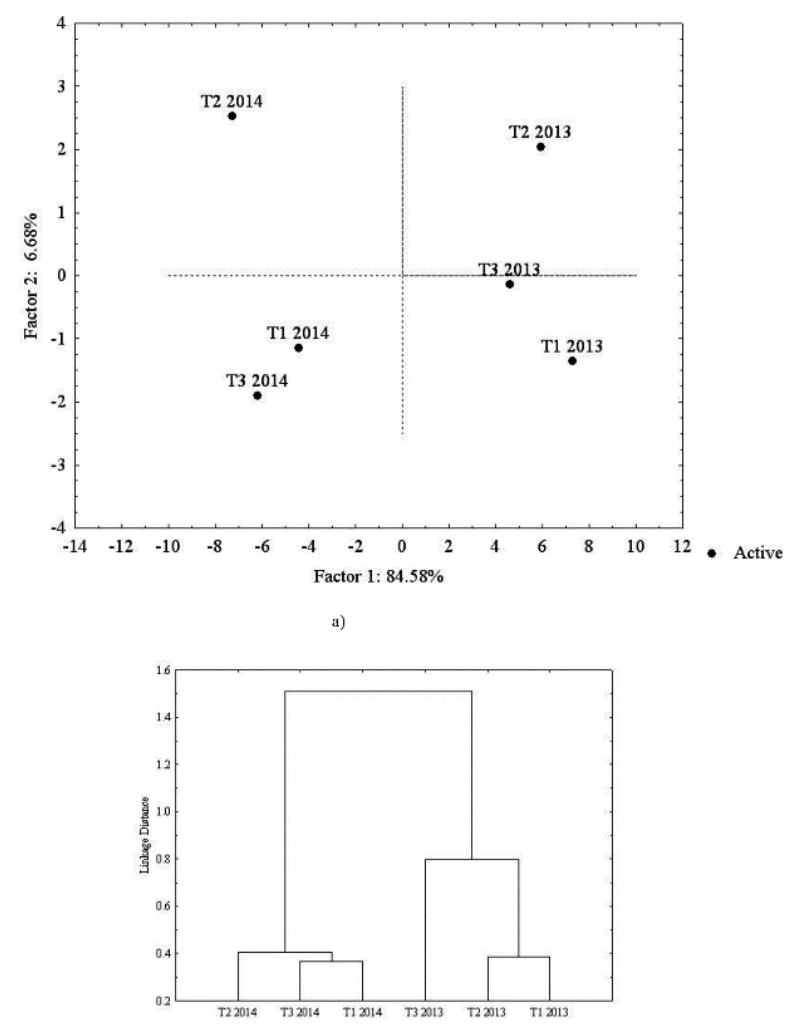

Figure 1. a) Two dimensional principal component analysis plot; b) dendrogram formed by cluster analysis of volatile compounds in Cabernet Sauvignon wines from seasons 2013 and 2014. T1 = Removal of 3 leaves; T2 $=$ Removal of $\mathbf{6}$ leaves; $\mathbf{T 3}=$ control (no leaf removal).

Slika 1. a) Dvodimenzijski grafički prikaz analize glavnih komponenti ; b) dendrogram formiran klasterskom analizom sadržaja hlapljivih spojeva u vinima sorte Cabernet Sauvignon godišta 2013 i 2014. T1 = Uklanjanje 3 lista; T2 = Uklanjanje 6 listova; $T 3$ = kontrola (bez uklanjanja listova) 


\section{ACKNOWLEDGEMENTS}

This research was supported by Vukovar-Srijem County, Croatia (project number 369). The authors thank GERSTEL GmbH \& Co.KG for support.

\section{REFERENCES}

1. Antonelli, A., Castellari, L., Zambonelli, C., \& Carnacini, A. (1999). Yeast influence on volatile composition of wines. Journal of Agricultural and Food Chemistry, 47(3), 1139-1144. https://doi.org/10.1021/jf9807317

2. Bubola, M., \& Peršurić, Đ. (2012). Yield components, vegetative growth and fruit composition of 'Istrian Malvasia' (Vitis vinifera L.) as affected by the timing of partial defoliation. Agriculturae Conspectus Scientificus, 77(1), 21-26. https://hrcak.srce.hr/77898

3. Bubola, M., Peršurić, Đ., Kovačević Ganić, K., Karlogan, M., \& Kozina, B. (2012). Effects of fruit zone leaf removal on the concentrations of phenolic and organic acids in Istrian Malvasia grape juice and wine. Food Technology and Biotechnology, 50(2). 159-166. https://hrcak.srce. $\mathrm{hr} / 83361$

4. Chapman, D. M., Roby, G., Ebeler, S.E., Guinard, J. X., \& Matthews, M. A. (2005). Sensory attributes of Cabernet Sauvignon wines made from vines with different water status. Australian Journal of Grape and Wine Research, 11(3), 339-187. https://doi. org/10.1111/j.1755-0238.2005.tb00033.x

5. Diäaz-Maroto, C., Schneider, R., \& Baumes, R. (2005). Formation pathways of ethyl esters branched short-chain fatty acids during wine aging. Journal of Agricultural and Food Chemistry. 53(9), 3503-3509. http://dx.doi. org/10.1021/jf0481570

6. Dunlevy J., Kalua C., Keyzers R., Boss P. (2009). The Production of Flavour \& Aroma Compounds in Grape Berries. In: Roubelakis-Angelakis K.A. (eds) Grapevine Molecular Physiology \& Biotechnology. Springer, Dordrecht. https://doi.org/10.1007/978-90-481-23056_11

7. Feng, H., Yuan, F., Skinkis, P. A., \& Qian, M. C. (2015). Influence of cluster zone leaf removal on Pinot noir grape chemical and volatile composition. Food Chemistry, 173: 414-423. https://doi.org/10.1016/j.foodchem.2014.09.149

8. Giovanelli, G., \& Brenna, 0. V. (2007). Evolution of some phenolics components, carotenoids and chorophylls during ripening of three Italian grape varieties. European Food Research and Technology, 225(5), 145-150. https:// doi.org/10.1007/s00217-006-0436-49

9. Guidoni, S., Oggero, G., Cravero, S., Rabino, M., Cravero, M. C., \& Balsari, P. (2008). Manual and mechanical leaf removal in the bunch zone (Vitis vinifera L., cv Barbera): effects on berry composition, health, yield and wine quality, in a warm temperate area. Journal International des Sciences de la Vigne et du Vin, 42(1), 49-58. https:// doi.org/10.20870/oeno-one.2008.42.1.831

10. Jiang, B., \& Zhang, Z. (2010). Volatile compounds of young wines from Cabernet Sauvignon, Cabernet Gernischet and Chardonnay varieties grown in the loess plateau region of China. Molecules, 15(2), 9184-9196. https://doi.org/10.3390/molecules 15129174
11. Kozina, B., Karlogan, M., Herjavec, S., Jeromel, A., \& Orlic, S. (2008). Influence of basal leaf removal on the chemical composition of Sauvignon Blanc and Riesling wines. Journal of Food, Agriculture \& Environment, 6(1), 28-33. https://agris.fao.org/agris-search/search. do? recordID $=$ US201300903843

12. Mijowska, K., Ochmian, I., \& Oszmiański J. (2016). Impact of cluster zone leaf removal on grapes cv. regent polyphenol content by the UPLC-PDA/MS method. Molecules, 21(12), 1688.

http://doi.org/10.3390/molecules21121688

13. Moreira, J. L., \& Santos, L. (2005). Analysis of organic acids in wines by Fourier-transform infrared spectroscopy. Analytical and Bioanalytical Chemistry, 382(2), 421-425. https://doi.org/10.1007/s00216-005-3062-2

14. Moreno, D., Valdés, E., Uriarte, D., Gamero, E., Talaverano, I., \& Vilanova, M. (2017). Shoot and cluster thinning influence vegetative growth, fruit yield, and wine quality of 'Sauvignon blanc' grapevines. Food Research International, 98, 50-58. http://doi. org/10.1016/j.foodres.2016.09.017

15. Oliveira, J., Sá, F., Barros, F. \& Araújo, I. (2006). C6-alcohols as varietal markers for assessment of wine origin. Analytica Chimica Acta, 563(1-2), 300-309. https://doi.org/10.1016/j.aca.2005.12.029

16. Preston, L. D., Block, D. E., Heymann, H., Soleas, G., Noble, A., \& Ebeler, S. E. (2008). Defining vegetal aromas in Cabernet Sauvignon using sensory and chemical evaluations. American Journal of Enology and Viticulture, 59(2), 137-145.

17. Rapp, A., \& Mandery, H. (1986). Wine aroma Experientia, 42: 873-884. https://doi.org/10.1007/ BF0194176410.1007/BF01941764

18. Reynolds, A. G., Edwards, C. G., Wardle, D. A., Webster, D., \& Dever, M. (1994). Shoot density affects 'Riesling' grapevines II. Wine composition and sensory response. Journal of the American Society for Horticultural Science, 119(5), 881-892. http://journal.ashspublications.org/ content/119/5/881.full.pdf

19. Sánchez-Palomo, E., García-Carpintero, E. G., Gallego, M. Á. G., \& Viñas, M. A. G. (2012). The aroma of rojal red wines from La Mancha region - Determination of key odorants, In Salih B. (ed.) Gas chromatography in plant science, wine technology, toxicology and some specific applications, Rijeka: In Tech.

20. Smith, S., Codrington, I. C., Robertson, M., \& Smart, R. E. (1988). Viticultural and oenological implications of leaf removal for New Zealand vineyards. Proceedings Second International Cool Climate Viticulture and Oenology, Auckland, New Zealand, 127-133. http://www.englishwine.com/viticultural_implications_of_leaf_removal_ in nz.pdf

21. Šuklje, K., Antalick, G., Coetzee, Z., Schmidtke, L. M., Baša Cesnik, H., Brandt, J., du Toit, W. J., Lisjak, K., \& Deloire, A. (2014). Effect of leaf removal and ultraviolet radiation on the composition and sensory perception of Vitis vinifera L. cv. Sauvignon Blanc wine. Australian Journal of Grape and Wine Research, 20(2), 223-233. https://doi.org/10.1111/ajgw.12083

22. Tao, Y., \& Zhang, L. (2010). Intensity prediction of typical aroma characters of Cabernet Cauvignon wine in Changli 
County (China). LWT - Food Science and Technology, 43(10), 1550-1556. https://doi.org/10.1016/j. Iwt.2010.06.003

23. Tardaguila J., Martinez de Toda, F., Poni S., \& Diago M. P. (2010). Impact of early leaf removal of yield and fruit and wine composition of Vitis vinifera $L$. Graciano and Carignan. American Journal of Enology and Viticulture, 6(3), 372-381. https://www.researchgate. net/profile/Javier_Tardaguila/publication/260405536 Impact of early leaf removal on yield and fruit and_wine_composition_of Vitis_vinifera_L_Graciano-

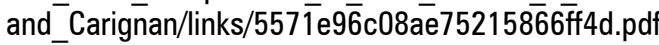

24. Verzera, A., Tripodi, G., Dima, G., Condurso, C., Scacco, A., Cincotta, F., Giglio, D. M., Santangelo, T. \& Sparacio, A. (2016). Leaf removal and wine composition of Vitis vinifera L. Cv. Nero d'Avola: the volatile aroma constituents. Journal of the Science of Food and Agriculture, 96(1), 150-159. https://doi.org/10.1002/jsfa.7075

25. Vilanova, M., Diago, M. P., Genisheva, Z., Oliveira, J. M., \& Tardaguila J. (2012). Early leaf removal impact on volatile composition of Tempranillo wines. Journal of the Science of Food and Agriculture, 92, 935-942. https:// doi.org/10.1002/jsfa.4673

26. Volschenk, H., Van Vuuren, H. J. J. \& Viljoen-Bloom, M. (2006). Malic acid in win: origin, function and metabolism during vinification. South African Journal of Enology \& Viticulture, 27(2),123-136, https://doi. org/10.21548/27-2-1613.25

27. Xi, Z.M., T ao, Y.S., Zhang, L., \& Li, H. (2011). Impact of cover crops in vineyard on the aroma compounds of Vitis vinifera L. cv Cabernet Sauvignon wine. Food Chemistry, 127(2), 516-522. https://doi.org/10.1016/j. foodchem.2011.01.033

28. Zhang, P., Wu, X., Needs, S., Liu, D., Fuentes, S., \& Howell, K. (2017). The influence of apical and basal defoliation on the canopy structure and biochemical composition of Vitis vinifera cv. Shiraz grapes and wine. Frontiers in Chemistry, 5, 48. https://doi.org/10.3389/ fchem.2017.00048

\title{
UČINCI RANOG UKLANJANJA LISTOVA NA KONCENTRACIJE HLAPLJIVIH SPOJEVA U CABERNET SAUVIGNON VINIMA IZ VINOGORJA ILOK
}

\begin{abstract}
SAŽETAK
Cilj ovoga dvogodišnjeg istraživanja bio je procijeniti učinke uklanjanja bazalnoga lista prije cvatnje na sadržaj hlapljivih spojeva Cabernet Sauvignon vina u vinogradima Ilok (istočna Hrvatska). Tijekom dviju uzastopnih godina (2013. i 2014.) primijenjena su dva različita tretmana uklanjanja bazalnih listova: uklanjanje 3 lista, 6 listova te kontrola bez uklanjanja listova. Hlapljivi spojevi dobivenih vina identificirani su i kvantificirani spregnutom tehnikom plinske kromatografije $i$ spektrometrije masa. Tretmani rane defolijacije nisu imali učinka na koncentraciju organskih kiselina i viših alkohola, osim na octenu kiselinu i 2-metil-6-hepten-1-ol. Rana defolijacija utjecala je koncentracije šest estera samo u vinima iz 2014. godine s različitim ishodom. Za spojeve na koje rana defolijacija nije imala učinka, berba je bila statistički značajan izvor varijabilnosti, kao što su rezultati multivarijantne analize potvrdili. Tretmane rane defolijacije u Cabernet Sauvignon vinima u istočnome kontinentalnome dijelu Hrvatske potrebno je prilagoditi vremenskim prilikama tijekom vegetacijske sezone.
\end{abstract}

Ključne riječi: uklanjanje listova, vino, hlapljivi spojevi, plinska kromatografija

(Received on 13 April 2018; accepted on 16 May 2018 - Primljeno 13. travnja 2018.; prihvaćeno 16. svibnja 2018.) 